\title{
MÁSCARAS DA MORTE EM ÁLVARES DE AZEVEDO
}

\section{MASKS OF DEATH IN ÁLVARES DE AZEVEDO}

Paulo Sérgio MARQUES ${ }^{56}$

RESUMO: O objetivo deste artigo é contribuir na análise sobre o tema da Morte na poesia de Álvares de Azevedo. O individualismo é um dos traços característicos do sentimento romântico. Para o sociólogo Edgar Morin, é o senso de individualidade que faz o homem notar e temer a Morte, por isso este se torna um dos temas principais da poesia romântica. Álvares de Azevedo destaca-se dentre nossos poetas da Morte. Em "O poeta moribundo", o autor corrói a imagem da Morte por meio do sarcasmo e do riso sardônico, elementos que mascaram o terror do Eu diante da aniquilação.

PALAVRAS-CHAVE: Poesia brasileira; Romantismo; Álvares de Azevedo; Morte.

ABSTRACT: The objective of this paper is to contribute in the analysis about the theme of Death in the poetry of Álvares de Azevedo. Individualism is a romantic sensibility's typical trait. By the sociologist Edgar Morin, sense of individuality conducts human being to perceive and fear the Death, for that, Death is romantic poetry's one of principal topics. Álvares de Azevedo is detached from our Death's poetry. In "O poeta moribundo" the author erodes Death's image, by means of sarcasm and sardonic laughing, elements that mask the Self's horror in front of annihilation.

KEYWORDS: Brazilian poetry; Romanticism; Álvares de Azevedo; Death.

\footnotetext{
${ }^{56}$ Doutorando do Programa de Pós-Graduação em Estudos Literários (Bolsista CAPES) - Faculdade de Ciências e Letras - Universidade Estadual Paulista (UNESP), campus de Araraquara - CEP 14800-901 Araraquara - SP - Brasil - E-mail: santiagovillelamarques@gmail.com
} 
Na obra dos ditos "poetas ultrarromânticos", a Morte é tema recorrente, e, dentre eles, Álvares de Azevedo tem sido o mais identificado pela crítica com uma poética da morbidez. Para Antônio Soares Amora (1969, p. 157), foi a poesia "em que expressou seu sentimento da morte" que "mais conquistou o público e consagrou definitivamente o jovem poeta paulista”.

Da poesia azevediana sobre a Morte, "O poeta moribundo" (sexto poema de "Spleen e charutos", da segunda parte da Lira dos vinte anos) é notável exemplar:

Poetas! amanhã ao meu cadáver

Minha tripa cortai mais sonorosa!...

Façam dela uma corda e cantem nela

Os amores da vida esperançosa!

Cantem esse verão que me alentava...

$\mathrm{O}$ aroma dos currais, o bezerrinho,

As aves que na sombra suspiravam,

E os sapos que cantavam no caminho!

Coração, por que tremes? Se esta lira

Nas minhas mãos sem força desafina,

Enquanto ao cemitério não te levam,

Casa no marimbau a alma divina!

Eu morro qual nas mãos da cozinheira

O marreco piando na agonia...

Como o cisne de outrora... que gemendo

Entre os hinos de amor se enternecia.

Coração, por que tremes? Vejo a morte,

Ali vem lazarenta e desdentada...

Que noiva!... E devo então dormir com ela?

Se ela ao menos dormisse mascarada!

Que ruínas! que amor petrificado!

Tão antediluviano e gigantesco! 
Ora, façam ideia que ternuras

Terá essa lagarta posta ao fresco!

Antes mil vezes que dormir com ela,

Que dessa fúria o gozo, amor eterno...

Se ali não há também amor de velha,

Dêem-me as caldeiras do terceiro inferno!

No inferno estão suavíssimas belezas

Cleópatras, Helenas, Eleonoras;

Lá se namora em boa companhia,

Não pode haver inferno com Senhoras!

Se é verdade que os homens gozadores, Amigos de no vinho ter consolos,

Foram com Satanás fazer colônia,

Antes lá que do Céu sofrer os tolos!

Ora! e forcem um'alma qual a minha,

Que no altar sacrifica ao Deus-Preguiça,

A cantar ladainha eternamente

E por mil anos ajudar a Missa! 
(AZEVEDO, [19_], p.59-60).

\section{Morte e individualismo romântico}

A Morte sempre foi tema da poesia, mas a morte clássica aparece como elemento algo distante do sujeito poético e comum a todo o gênero humano, uma ameaça coletiva que estimula ao bem-viver e convida ao carpe diem. No Romantismo, ao contrário, a Morte sofre a influência de princípios individualistas, uma das principais marcas - senão a maior - do movimento, como observa Antonio Candido (1997, p. 22).

O sociólogo Edgar Morin ([1988], p. 32) adverte sobre o vínculo profundo entre sentimento de morte e senso de individualidade: "O horror da morte é [...] a emoção, o sentimento ou a consciência da perda da individualidade". Por isso, ele nota que "a partir da segunda metade do século XIX inicia-se uma crise de morte", que, corroendo o seu próprio conceito, “corrói então os outros conceitos, mina os pontos de apoio do intelecto, derruba as verdades, niiliza a consciência", engendrando uma "crise da individualidade perante a morte" (MORIN, [1988], p. 261). Diante da irrupção do indivíduo no pensamento e nas artes, seria, pois, inevitável que também os invadisse um sentimento da Morte intenso, profundo e particularizado. Não é à toa que o Romantismo cultue tanto a Morte: só quando a individualidade se torna valor máximo pode a Morte elevar-se de sua posição orbital para a de assunto nuclear nas artes e na literatura.

Inversamente, quando a individualidade submerge num sentido de vida coletiva, o horror da Morte desaparece, como ocorre nos atos de guerra e nas batalhas, em que os soldados parecem perder o medo da Morte em benefício de um ideal pátrio. "O horror da morte depende estreitamente da independência do indivíduo em relação ao seu grupo", afirma Morin ([1988], p. 36), e, "reciprocamente, a presença imperativa do grupo aniquila, repele, inibe ou adormece a consciência e o horror da morte". Esse sentimento de solidariedade grupal está, contudo, abolido do espírito romântico: "O individualismo, destacando o homem da sociedade ao forçá-lo sobre o próprio destino, rompe de certo modo a ideia de integração, de entrosamento - quer dele próprio com a sociedade em que vive, quer desta com a ordem natural entrevista pelo século XVIII" (CANDIDO, 1997, p. 23).

Por sua afronta à individualidade, a Morte se torna o grande interdito do século e, consequentemente - já que a literatura é o lugar do interdito -, tema privilegiado nas 
páginas dos poetas românticos. Comentando observação do sociólogo inglês Geoffrey Gorer, o historiador Philippe Ariès observa "como a morte tornou-se um tabu e como, no século XX, substituiu o sexo como principal interdito". Ele explica que, "quanto mais a sociedade relaxava seus cerceamentos vitorianos ao sexo, mais rejeitava as coisas da morte. E, junto com o interdito, aparece a transgressão: na literatura macabra reaparece a mistura do erotismo e da morte" (ARIÈS, 2003, p. 89).

É o que parece ocorrer com o poema de Álvares de Azevedo, cuja obra, nas palavras do crítico Eugênio Gomes (1997, p. 139), "é a primeira afirmação realmente notável do individualismo romântico no Brasil" e despertou este comentário de Alfredo Bosi (1993, p. 122): “A evasão segue, nesse jovem hipersensível, a rota de Eros, mas o horizonte último é sempre a morte". Bosi, aliás, também percebe a associação da Morte com o individualismo, na literatura romântica:

\begin{abstract}
A oclusão do sujeito em si próprio é detectável por uma fenomenologia bem conhecida: o devaneio, o erotismo difuso ou obsessivo, a melancolia, o tédio, o namoro com a imagem da morte, a depressão, a autoironia masoquista: desfigurações todas de um desejo de viver que não logrou sair do labirinto onde se aliena o jovem crescido em um meio romântico-burguês em fase de estagnação. (BOSI, 1993, p. 120; grifo meu).
\end{abstract}

E é justamente numa situação de "namoro" com o eu-lírico que a figura da Morte aparece na passagem central de "O Poeta Moribundo". O poema em dez quadras de decassílabos rimados nos versos pares (ABCB) começa como uma espécie de testamento, em que o eu-lírico conclama os poetas a que, depois de morto, profanem seu cadáver para lhe arrancar as tripas, com as quais deverão cantar a vida que ele deixou. De solilóquio, o texto passa em seguida a monólogo, em que o poeta interpela o próprio coração, buscando acalmá-lo diante da ideia de morrer. A aproximação da Morte é então apresentada como um noivado, no qual ele deve desposá-la. Diante da Morte, ele investiga suas "qualidades" e reflete sobre a condição do homem morto, concluindo que, para um indivíduo com seus hábitos e gostos, melhor é fazer companhia aos boêmios e devassos do inferno do que passar a eternidade rezando no céu. Esta exposição pode ser dividida em pelo menos sete momentos: 1$)$ invocação ( $1^{\mathrm{a}}$ estrofe); 2 ) 
testamento ( $1^{\mathrm{a}}$ e $2^{\mathrm{a}}$ estrofes); 3$)$ anúncio da Morte ( $4^{\mathrm{a}}$ estrofe); 4) núpcias com a Morte ( $5^{\mathrm{a}}$ estrofe); 5) reconhecimento da condição de morto ( $6^{\mathrm{a}}$ estrofe); 6) comparação dos prazeres da Vida com as cruezas da Morte ( $7^{\mathrm{a}}$ e $8^{\mathrm{a}}$ estrofes); 7) opção pelo inferno no post-mortem ( $9^{\mathrm{a}}$ e $10^{\mathrm{a}}$ estrofes).

O aproveitamento da sugestão sonora, por meio de assonâncias, coliterações, rimas e outros paralelismos e figuras de harmonia, assegura a "O poeta moribundo" musicalidade ímpar e um esmerado ajuste entre significados e significantes. Predominam foneticamente as vogais fechadas e os fonemas nasais $(/ \mathrm{m} /, / \mathrm{n} /$, /ã $/)$, conferindo ao poema um tom crepuscular. Em momentos de singularidades emocionais, esses fonemas ainda são aproveitados para acentuar um sentimento mais desesperado ou uma imagem relevantemente sombria. Em "o marreco piando na agonia" (verso 14), as nasais se acumulam desarmonicamente num verso cacofônico para combinar com a dissonância musical do marreco agonizante. Compare-se o verso com o que lhe segue para registrar o canto do cisne: "Entre os hinos de amor se enternecia" (verso 16). Aqui, a aspereza do encontro consonantal de "entre" é abrandada no final do verso pela repetição da palavra com os fonemas finais em posição trocada - "enter" -, de maneira que a vogal interior confira agora leveza e fluidez sonora, qualidades acentuadas pela presença das fricativas linguodentais, utilizadas em outros versos também como atenuantes temáticas, tais como o verso 7 - "as aves que na sombra suspiravam" - e o verso 10 - "nas minhas mãos sem força desafina"; no primeiro a coliteração imita o canto sussurrante dos pássaros, enquanto no segundo parece chiar como a música desafinada da lira do poeta. Já neste outro verso de sonoridade anasalada: "tão antediluviano e gigantesco" (verso 22), tomado na quase totalidade de sua extensão por dois únicos vocábulos, a repetição simétrica da sílaba /an/ aliada à dilatação dos vocábulos aumenta a sensação de profundidade temporal e espacial conferida à Morte.

A predominância das fechadas e nasais cria ainda um tom de fundo para realces temáticos e emocionais pelo contraste com sons e timbres mais abertos. É o que ocorre logo no início do poema, quando, à palavra absolutamente anasalada "amanhã", sucedem as tônicas mais abertas: "Poetas! amanhã ao meu cadáver / minha tripa cortai mais sonorosa", para dar forma bradada à agressividade do pedido. O mesmo parece ocorrer com a assonância em /i/ da estrofe final, manifestando a irritação e a revolta do eu-lírico no termo da confissão. Desse modo, embora marcado em seu corpo pelas 
aliterações de tom baixo, o poema começaria e terminaria com fonemas mais abertos ou estridentes. Esse contraste sonoro parece ampliar, ao nível do poema, aquela contradição sintetizada na quarta estrofe e comentada acima, entre o canto do cisne e o pio do marreco, expressiva das duas situações emocionais que dão armadura à tensão do poema: de um lado a vida do poeta; do outro, sua morte e ruína.

Temporalmente, a expressão inicia-se no futuro (“amanhã”) em que se prevê a fatalidade da Morte e a partir do qual se vê o presente como um passado (o verão "alentava", as aves "suspiravam", os sapos "cantavam" - $2^{\mathrm{a}}$ estrofe). Agora a atenção do eu-lírico se volta para esse presente, já pressentido como uma futura perda: o coração treme, as mãos não têm força para tocar a lira, que desafina. O nada acentua no ser o sentimento de si, e o poeta se propõe o canto como consolo na espera da hora derradeira: "Enquanto ao cemitério não te levam, / Casa no marimbau a alma divina" (versos 11 e 12). Na estrofe seguinte a morte futura se torna sentimento presente ("eu morro") e se confronta com o passado do poeta ("cisne de outrora”). A partir daí, a Morte é sentida como presença, é vista, "vem" (versos 17 e 18) ao poeta para ser contemplada e meditada. É quando o movimento entre os tempos estaciona em versos dissertativos, para expor juízos do eu-lírico a respeito da Morte, como se o próprio movimento da Vida estagnasse e mergulhasse o Eu nos abismos do pensamento puro. Há aí um isolamento do sujeito, como aqueles a que toda morte obriga, um retorno da consciência sobre si mesma, seus valores, seus sentimentos e suas reflexões.

Como se nota pela passagem do vocativo "Poetas!" (verso 1) ao de "Coração!" (versos 9 e 17), embora o sujeito que fala comece o poema dirigindo-se a um segundo, estabelecendo, assim, as premissas de um diálogo, essa segunda voz não encontra expressão no texto, servindo apenas de ouvinte necessário à confissão do eu-lírico. Este se encaminha aos "poetas" com verbos imperativos - "cortai", "façam", "cantem" -, designativos da vontade do sujeito que fala sobre a daqueles que ele invoca. Por esses verbos, percebemos ainda o lugar dos "poetas" cedendo gradualmente passagem à expansão dos sentimentos do eu-lírico, na transição do verbo em segunda pessoa para os de primeira. Além disso, dois pronomes possessivos acumulados logo nos primeiros versos também impedem que a atenção se desvie do sujeito da fala para aqueles a quem ele se dirige: "meu cadáver", "minha tripa". Finalmente, na passagem que invoca pela segunda vez o "coração", este se identifica com o sujeito num verbo de primeira pessoa: 
“Coração, por que tremes? Vejo a morte" (verso 9). A afirmação do eu-lírico de que vê a Morte parece antes uma resposta do coração à pergunta que a precede, e por essa coincidência de sentidos faz-se a reunião do coração com o sujeito que o interpelava.

A anunciada morte do eu-lírico é, pois, o verdadeiro assunto de todo o poema, lamento pessoal contra a presença da Morte, aqui particularizada - personificada, até - e sofrida como o destino forçoso e deplorável de um Eu. Assim, ao contrário do que costuma ocorrer na poesia da geração ultrarromântica, a Morte neste poema não aparece como fim desejado, o que se pode concluir a partir das qualidades a ela atribuídas no percurso do poema.

Em primeiro lugar, a Morte aparece como ameaça assustadora: o coração "treme", as mãos tocam a lira "sem força" (versos 9 e 10). A ameaça é a da decomposição e ruína do Ser, pela qual o indivíduo perderia uma vida de prazeres, cuja abundância é sentida pela acumulação de sentenças e pelo paralelismo dos versos da segunda estrofe. A "esses amores da vida esperançosa” opôs-se já o cadáver com sua presença de consciência decomposta, tensão que também se denuncia no decaimento de "cisne" para "marreco" e na anunciação das "ruínas" (verso 21) e do "amor de velha" (verso 27). Também a lagarta do verso 24 remete metonimicamente à ideia de decomposição, por sua associação com o verme.

A Morte é também a paralisação do movimento, no assunto do poema assumido como o canto do poeta. É o "amor petrificado" (verso 21), "antediluviano e gigantesco", adjetivos que ainda lhe traem os atributos de antiguidade (tempo) e extensão (espaço), mostrando sua condição de destino inelutável. Essa fatalidade da Morte é o que a veste alegoricamente, no poema, com a figura da noiva, aquela que é prometida. Não é uma noiva escolhida e desejada, mas imposta. A recusa do eu-lírico aparece nos adjetivos conferidos à consorte: "lazarenta e desdentada" (verso 18), em que a magistral combinação das alveolares com a fricativa sonora, no início, às oclusivas dentais, ao final, confina em dois vocábulos toda a sugestão de rispidez, rugosidade e claudicância que a Morte traz ao poeta.

Finalmente, a Morte parece assustar por aquela associação, já proposta secularmente por Anaximandro, entre corrupção física e corrupção moral, como observou Nietzsche, nesse comentário sobre o pré-socrático: “É bem humano [...] considerar agora, com Anaximandro, todo vir-a-ser como uma emancipação do ser 
eterno, digna de castigo, como uma injustiça que deve ser expiada pelo sucumbir." (NIETZSCHE, 1989, p. 17). Assim, tudo que nasceu deve perecer, e viver e sofrer a Morte são punições por ter a criatura se apartado do Todo. A última face da Morte no poema é, pois, a de processo punitivo, de onde surgem as imagens infernais apresentadas nas estrofes finais, bem como o adjetivo "fúria" para a Morte (verso 26), pois, de um lado, essa emoção só pode ser atribuída à Morte, no contexto, se a consideramos como uma personagem vingadora; de outro, "fúria" remete ao outro nome das Erínias, aquelas divindades greco-romanas encarregadas de fazer os criminosos expiarem suas culpas.

A Morte não é, pois, bela para o poeta moribundo, como não o é para ninguém que tenha a individualidade bastante fortalecida. Parece-me que é desta falta de beleza que nasce o amor do ultrarromântico pela Morte: não é por sofrer que ele quer a Morte, mas antes ele a quer para poder sofrê-la; desejar a Morte não é sintoma de fuga da dor, mas um avanço até a dor mais profunda. O ultrarromântico atualiza Anaximandro: viver é sofrer a Morte, que é a pena pela culpa de estar vivo. Na opção pela Morte, o poeta do mal-doséculo opta pela Vida em sua substância: o caminho para a dissolução. Não se podia esperar outra coisa de uma geração superindividualista: uma boa consciência de Morte não poderia ser conclusão senão de um raro sentido de Vida e de Ser. É nessa oposição entre Vida e Morte, entre Ser e Nada, que deve ser considerada a atração azevediana pelo mórbido, como já o notou Antonio Candido: "Por isso, parecem-nos [os poetas da segunda geração] definitiva e irremediavelmente românticos, pois vivem no espírito e na carne um dos postulados fundamentais do movimento - a volúpia dos opostos, a filosofia do belo-horrível” (CANDIDO, 1997, p. 133). Com essa percepção penetrante que tem a individualidade exaltada - das contrariedades da Vida, a beleza ganha estranhos contornos, pois, se estar vivo é o pressuposto dos prazeres, também significa ter a Morte pressuposta. A Morte não é, portanto, desejada porque é boa ou bela, mas porque é a maior dor do Ser.

\section{Uma caveira risonha}

É ainda nesse sentido que interpreto o humor azevediano no trato com a Morte, em "O poeta moribundo". Aqui, sim, há que se ver fuga e evasão. Muito se disse da vertente auto-irônica do Romantismo na poesia de Álvares de Azevedo; nem todos os 
seus leitores, porém, relacionaram-na, como Alfredo Bosi, a um movimento evasionista: "Na segunda parte da Lira", prega o crítico, "a fuga tem por nomes dispersão, autoironia, confidência: uma espécie de cultivado spleen que lembra o último Musset ao dirigir o seu sarcasmo contra os ultrarromânticos” (BOSI, 1993, p. 123; grifos meus).

"O poeta moribundo", como já apontado, é o último poema de "Spleen e charutos", série da segunda parte da Lira dos vinte anos, composta de seis poemas que tratam o tédio, a melancolia e o platonismo do eu-lírico com humor e ironia. Sobre a qualidade dessa poesia, diz Antonio Candido (1997, p. 169-170): “As seis poesias da série 'Spleen e Charutos' formam um conjunto excepcional em nossa literatura, pela alegria saudável, graciosa, a dosagem exata do humor, podendo algumas ser consideradas pequenas obras-primas no gênero" e estão entre os "momentos de maturidade deste adolescente".

Maturidade implica em pelo menos duas condições: em primeiro lugar, é a hora em que os valores e sentimentos chegam a uma expressão mais equilibrada e menos patética do que as cores que exibiam na juventude; mas é também o momento em que tais valores e sentimentos se consolidam, e é por essa solidez que porventura atingem aquele equilíbrio. É preciso, pois, entender a segunda parte da Lira, não como uma contradição ou negação da primeira, mas sua consequência lógica no interior de uma consciência que evolui no seu sentimento da Vida e das coisas.

"O poeta moribundo" dialoga com outros poemas do autor, como "Lembrança de morrer" (primeira parte da Lira) e "Se eu morresse amanhã" (Poesias Diversas), nos quais a antecipação da própria morte conduz a uma nênia autodestinada, um choro romanticamente egocêntrico do eu-lírico pelo fim previsto - isto é, destinado - e antevisto - isto é, pressentido e contemplado no presente. Em "O poeta moribundo", a nênia transforma-se em poema humorístico, e a "decaída" poderia sugerir uma recusa do sentimento romântico pela dor da Morte, uma "nova" consciência, mais autocrítica e menos lastimosa. Não obstante, no que diz respeito à Morte, é ainda a mesma consciência, e o humor da segunda parte das liras permanece um sintoma do egocentrismo ultrarromântico e não exatamente sua superação pela autocorrosão, pois o riso e a exposição obscena do macabro são ainda consequências extremas do sentimento intenso da Morte pelo indivíduo. Não esqueçamos, aqui, o "marreco piando na agonia": a decaída de tons líricos na poesia é maior no instante do sacrifício; quando mais 
próxima a Morte, maior o pendor para a zombaria e o escárnio, pois só desacreditando a Morte - e desacreditando-se - a individualidade se impede de não querer ser morta.

Torna-se necessário, neste ponto, fazer distinções entre o simplesmente mórbido e o macabro. A morbidez diz respeito a um estado patológico ou doentio, um temperamento ou uma emoção hipocondríacos ou melancólicos, circunstâncias afetivas aparentadas com a Morte. Macabro, contudo, é um adjetivo que designava precipuamente uma "dança alegórica que representa a morte" (CUNHA, 1997, p. 485), isto é, uma conversão do mórbido em motivo de riso e festejo.

O comportamento macabro decorre de uma intensificação do sentido da ruína inevitável, de uma consciência da derrota diante do derruimento do corpo e do Ser. É a reação revoltada do indivíduo frente à percepção do cadáver: "A decomposição é o sinal do fracasso do homem, e neste ponto reside, sem dúvida, o sentido do macabro" (ARIÈS, 2003, p. 56). É dessa forma que, em Álvares de Azevedo, a impotência diante da Morte converte-se em desdém e sarcasmo. Quando um sentimento egotista acentuado enxerga o perigo da decomposição, o cadáver precisa ser exposto e dissecado pelo riso. Aliás, a decomposição da carne revela que, no íntimo, a Morte é um sarcasmo. "O riso e a morte fazem boa mistura", defende Georges Minois (2003, p. 29). "É suficiente olhar um crânio para se convencer: nada pode roubar-lhe o eterno sorriso." O autor recorda o episódio final da Odisseia, quando os pretendentes de Penélope, "pressentindo seu fim próximo, são sacudidos por um riso que agita seus maxilares contra sua vontade - o riso inextinguível dos deuses - e, ao mesmo tempo, choram" (MINOIS, 2003, p. 27). Vê-se porque, se a "essência do Romantismo" reside, como defendem Anatol Rosenfeld e J. Guinsburg (1978, p. 270), na “contradição", não existe tema então mais romântico do que a Morte.

$\mathrm{O}$ riso é ingrediente natural ao sentimento de Morte. O inelutável só permite duas reações concomitantes: de um lado, ser aceito, mas, ao mesmo tempo, ser submetido ao lenitivo do humor para ser bem suportado. Citando Salomon Reinach, Minois alerta que "o riso desempenha uma função mágica que permite a passagem para uma nova vida e significa o consentimento das vítimas" (MINOIS, 2003, p. 27). O riso sardônico é um riso obrigado e provavelmente leva esse nome porque os antigos acreditavam que uma planta venenosa, a sardônia, produzia em suas vítimas espasmos musculares que imitavam o riso espontâneo; é a expressão 
[...] de qualquer um que, "mordido inteiramente pela cólera ou pelo desgosto, ri com o canto da boca, contraindo-a e esticando-a. Sardanios em Homero, sardonios alhures designam um riso contraído e estirado, e sarcástico', explica Eustáquio [...]. O aspecto agressivo é realçado pelo fato de que a contração dos músculos da boca mostra os dentes, como o ressalta Hipócrates, que aproxima isso do riso da loucura. (MINOIS, 2003, p. 28).

O autor acrescenta que o riso sardônico "não exprime alegria daquele que é sua 'presa'”, mas, pelo contrário, associa-se à “ideia de sofrimento e de morte”. Mais do que isso, parece sempre ligado a casos de morte pelo fogo (MINOIS, 2003, p. 28) e situações em que a Morte é "vivida", isto é, sentida lentamente em seu processo de dor e destruição. Desse modo, o riso sardônico é, sim, um paliativo para a Morte, mas engendrado pela própria consciência da decomposição. Não é, portanto, uma solução que se anteponha, mas, antes, um sintoma terminal do ser que se sabe nascido para a Morte, daquele "que toma consciência de seu aniquilamento" (MINOIS, 2003, p. 29).

Em "O poeta moribundo", ao contrário dos citados "Lembrança de morrer" ou "Se eu morresse amanhã", o lamento pela aniquilação da Vida e dos prazeres terrenos nunca é exposto com o sentimento a descoberto, mas sempre contaminado por laivos de ironia. Na primeira estrofe, a tripa cortada ao cadáver desloca o sentido da "vida esperançosa" e o próprio pedido do moribundo, que abre o poema, já é colocado em dúvida: que esperança se pode cantar diante da iminência da Morte? Na estrofe seguinte, as imagens naturais do verão que o "alentava" são também ironicamente destituídas de seu status de objetos desejados: enquanto as aves "suspiram", são os sapos que cantam, o que antecipa o tom desarmônico da lira que "desafina" e do "pio do marreco" das duas estrofes seguintes; além disso, se numa primeira leitura - mais afetiva -, o "aroma" sugere estímulo agradável aos sentidos, logo o vemos combinar-se a "currais", substantivo que, numa leitura analítica, agirá sobre o adjetivo anteposto, desviando a primeira impressão para o significado implícito, naquele, de "mau-cheiro". Já na terceira estrofe, a maior oposição se faz entre a "lira" e a "alma divina", de um lado, e o "marimbau", de outro. O lirismo e as virtudes espirituais enfraquecem diante 
do corpo temeroso, e a "alma divina" deve dançar agora ao batuque de tambor de um coração assustado.

A alegoria proposta a partir da quinta estrofe dá ensejo às zombarias contra a figura da Morte - "lazarenta e desdentada"; "Que noiva!... E devo então dormir com ela? / Se ela ao menos dormisse mascarada!" (versos 18 a 20); "ternuras" de "lagarta" (versos 23 e 24); "amor de velha" (verso 27) -, bem como à derrisão das crenças salvadoras do post-mortem - as "suavíssimas belezas" do inferno, onde "se namora em boa companhia" (versos 31 e 32), ao contrário do que ocorre no "céu dos tolos" (verso 36), onde, "por mil anos", se canta "ladainha" e se ajuda a missa (versos 39 e 40), ocupações avessas a quem "sacrifica ao Deus-Preguiça" (verso 38).

O riso, nos ultrarromânticos, não é, contudo, como disse anteriormente, apenas uma autocrítica irônica contra o pathos romântico, mas um contínuo dentro desse próprio sentimento de morbidez. É preciso não esquecer que o riso, ao contrário do que geralmente se aceita, é elemento noturno: Momo, seu representante no panteão grego, descende da linhagem divina sombria e alia-se, assim, à Noite, à Ruína, à Loucura, ao Sono, à Morte (MINOIS, 2003, p. 29), isto é, a toda a descendência do Caos, incluindo aí o próprio Eros. O riso é, pois, o principal elemento noturno da lírica irônica de Álvares de Azevedo, já que todos os demais, como a própria Morte, passam pelo seu filtro para atingirem a poesia nessa parte da Lira. Além disso, Momo é mascarado, o que quer dizer que age para ocultar alguma face indesejável das coisas. Nesse caso, sua presença em "O poeta moribundo" estaria, na verdade, maquiando uma verdade que o poeta não pode exibir diretamente.

Que o riso é um recurso de maquiagem do sofrimento de Morte em "O poeta moribundo", provam-no outras características estilísticas evidentemente "mascaradoras" no poema, como o equilíbrio do ritmo, os tropos eminentemente metonímicos e a filiação da estrutura a um gênero secular da arte "humorística". Todas elas servem para expor o sentimento de Morte de maneira indireta, ou seja, buscando fugir à tensão emotiva daquilo que Morin ([1988], p. 33) chama de "traumatismo da morte".

Comecemos pelo ritmo e pelo metro dos versos. O poema é construído em versos decassílabos, em sua maior parte heroicos, à exceção dos versos 25 e 28 , evidentemente sáficos, e talvez o 40, embora este, a considerar-se a semitonicidade da $2^{\mathrm{a}}$ e da $6^{\mathrm{a}}$ sílaba, ainda pudesse ser lido como um pentâmetro iâmbico quase perfeito. 
Antonio Candido nota que o decassílabo, "no meio da orgia melódica em que se desmandaram freqüentemente os poetas [românticos], permaneceu como esteio e elemento de equilíbrio, assegurando a continuidade plástica da evolução poética e a própria dignidade do lirismo" (CANDIDO, 1997, p. 36, grifos meus). O uso do decassílabo é, pois, um recurso para controle do sentimentalismo romântico, pois reduz a cadência rítmica de versos mais acentuadamente marcados, como seriam, por exemplo, as redondilhas, o verso anapéstico ou os octossílabos. Por outro lado, a opção pela predominância do heroico fortalece ainda mais o equilíbrio emocional, uma vez que se trata de verso da poesia épica e clássica, menos afeito às expressões líricas e igualmente menos explorado pelos poetas românticos (CANDIDO, 1997, p. 36). Álvares de Azevedo, ao contrário, não se arrisca na sonoridade fácil do sáfico, mas prefere o heroico para colocar a Morte em moldes menos favoráveis à expansão do sofrimento e dos arroubos emocionais que o traumatismo de morte geralmente suscitaria.

Com relação aos tropos presentes no poema, também eles são índices de mascaramento e de abordagem indireta do tema. Já é um lugar-comum considerar a metáfora a figura preferida dos românticos. Seu poder de transfigurar a realidade imediata por uma outra, mais afetivamente colorida, eleva-a realmente a recurso singular nos poemas que primam por criar atmosferas emocionais. "O poeta moribundo", entretanto, não exibe muitas metáforas. À exceção da alegoria que a associa à noiva, a Morte é metaforizada no "amor petrificado" e na "lagarta" (6 estrofe). Note-se, entretanto, que a lagarta funciona, como sugeri acima, antes como metonímia da Morte, por sua associação com o verme, do que propriamente como tropos metafórico. Acresçam-se as personificações do coração e das aves e sapos que cantam e suspiram na segunda estrofe e as comparações do poeta com o cisne e o marreco, e encerra-se o universo de figuras metafóricas do poema, marcado mais acentuadamente pela presença da metonímia, seja diretamente - os "amores", em lugar de todos os prazeres da "vida esperançosa" (verso 4); o "verão", para a vida terrena (verso 5); "levar ao cemitério", por morrer, e "casar no marimbau", por cantar (versos 11 e 12); "suavíssimas belezas", por mulheres bonitas (verso 29); "Senhoras", por mulheres dignas (verso 32) -, seja indiretamente, nas perífrases eufemizantes - 
"sacrifica ao Deus-Preguiça", por viver no ócio (verso 38); "ter consolos no vinho", por beber; e "fazer colônia com Satanás", por ir para o Inferno (versos 34 e 35).

Ducrot e Todorov distinguem a metáfora da metonímia, afirmando que, para a primeira, "um objeto é designado pelo nome de um objeto que lhe é associado na experiência" (DUCROT e TODOROV, 1998, p. 111), enquanto a metonímia emprega "uma palavra para designar um objeto ou uma propriedade que se encontram numa relação existencial com a referência habitual dessa palavra" (DUCROT e TODOROV, 1998, p. 254). Comentando a cadeia de significantes lacaniana, os autores observam que, enquanto "a condensação é uma metáfora", e "diz para o sujeito o sentido recalcado do seu desejo", o deslocamento, por sua vez, "é uma metonímia", isto é, “desejo de outra coisa que sempre falta" (DUCROT e TODOROV, 1998, p. 316). Por essas definições, percebemos que, enquanto a metáfora parece evocar com mais contornos o objeto tematizado, pois o associa sempre a uma outra presença maciça, um segundo objeto inteiramente presentificado aos sentidos do sujeito, a metonímia serpeia por suas contiguidades sem nunca abordá-lo diretamente. A metáfora insiste, assim, no sentimento das qualidades do objeto tematizado, enquanto a metonímia desvia o olhar de sua presença para outras relevâncias: suas causas, efeitos, procedências, etc. Por isso, Greimas e Courtés ([1983], p. 280) definem a metonímia como uma "metáfora 'desviante'”, já que ela ascende ou descende do objeto para semas, respectivamente, hiperotáxicos ou hipotáxicos, em vez de condensar-se no significado e na presença "absoluta" do objeto, como faz a metáfora, buscando outros objetos para intensificar-lhe e ampliar-lhe o sentido.

A predominância de metonímias no poema de Álvares de Azevedo indica, pois, como a imagem da Morte é a todo tempo explorada em suas contiguidades, sem que se arrisque a tocá-la no centro de seu ser e presença. Por outro lado, impede igualmente sua idealização por meio do discurso metafórico. Exposta em sua nudez, a Morte é, contudo, abordada sempre tangencialmente. Outro disfarce para o indivíduo que se apavora diante do contato da Morte; mais um sintoma evasionista, que evita experimentar a realidade diretamente, mas prefere evocá-la por meio de falseamentos e reticências. Daí a pertinência da síntese crítica de Antonio Candido para os poetas ultrarromânticos, quando introduz capítulo dedicado àquela geração, em seu Formação da literatura brasileira, com o intertítulo de "Máscaras", afirmando: 


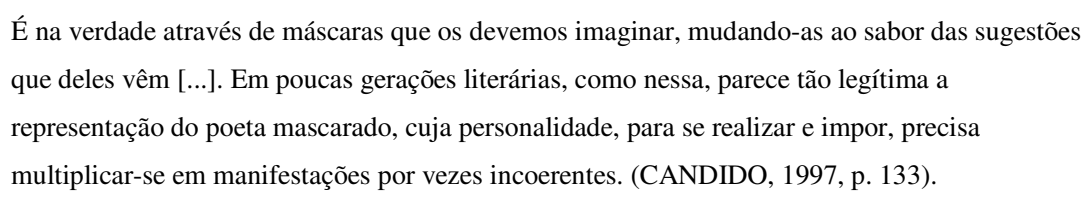

Em vista disso, o termo "mascarada", do verso 20, parece central na interpretação do poema. Se recordarmos que o riso - e especialmente a ironia - é "máscara" de Momo sobre o "verdadeiro" sentimento das coisas, a palavra "mascarada" seria um índice metalinguístico irônico para a leitura do próprio poema: as rimas da estrofe opõem "desdentada" a "mascarada", como a comparação anterior opusera o "cisne" ao "marreco". Lamenta o poeta que a noiva venha desdentada, quando a preferia mascarada; ora, é justamente assim que ele vai mostrá-la nas estrofes do poema: disfarçada, elidida, como quer o seu desejo e o seu medo individualista. Não a cantará mais como cisne, sentindo suas dores e suas sugestões líricas, mas como marreco, "piando" seus versos "desarmônicos", onde a Morte combina-se inopinadamente ao riso. Talvez ainda coubesse aqui a lembrança de que a palavra "marreco" guarda também sentidos conotados, como o de "astúcia" e "sagacidade", que atribuiriam ao poeta a manha sísifa de enganar a Morte com a troça.

Por outro lado, ao elaborar um poema que mascara a Morte com o humor, isto é, um poema verdadeiramente macabro, Álvares de Azevedo remete seu texto a formas artísticas que o antecedem, o da própria dança macabra, da qual "O poeta moribundo" surge, então, como uma atualização novecentista.

\section{A Morte mascarada}

Os tempos da Revolução Francesa viram ressurgir manifestações folclóricas e artísticas típicas das expressões populares desde pelo menos fins da Idade Média, na forma das mascaradas, em que

[...] desrecalque coletivo, violência e morte estão intimamente ligados [...]. Selvagem e inquietante, como a dança macabra, ela [a mascarada] expressa também a solidariedade dos participantes por seus ares de corrente humana, levada pelo riso. Sem chefe, ela serpenteia ao acaso, imagem de uma humanidade bêbada e louca. [...] 
Dança selvagem, opõe-se ao baile popular organizado, no qual o indivíduo está em primeiro lugar. (MINOIS, 2003, p. 472).

Essas mascaradas definiam-se, portanto, de um lado, pela associação de violência e morte ao riso e escárnio e, de outro, pela elisão do sentimento individualista. Nesse caso, o sentimento da Morte como experiência dolorosa do indivíduo ganharia contornos de destino coletivo e poderia, dessa forma, ser controlado pelo riso, impossível no sentimento personalista, pois o humor pressupõe o outro servindo de apoio à derrisão do sujeito que fala: "A farândola [...] também permite recalcar o medo, porque, nela, cada um é anônimo e integrado no todo. E é exatamente o riso que conduz à dança, riso caótico e sem fim, que farta, ensurdece e exorciza também a violência, o medo e a morte" (MINOIS, 2003, p. 472). Momo, o riso, destrona tudo o que parece nobre a olhos sentimentais. Não é por gratuidade que as mascaradas revolucionárias populares eram condenadas pelo próprio governo revolucionário, pois constituíam a crítica das massas ao andamento da nova sociedade que se erigia. "O riso é, de fato, a principal diferença entre a festa revolucionária oficial e a festa revolucionária espontânea”, revela Minois (2003, p. 472).

Um dos sentimentos das mascaradas revolucionárias era o anticlericalismo, que Minois (2003, p. 473) vincula a festividades medievais de espírito semelhante, como a festa do asno e a festa dos bobos da baixa Idade Média. Nessas celebrações, a ordem universal e a hierarquia terrena eram postas em ridículo e perdiam a seriedade axiológica. Nos tempos revolucionários, "o riso é, pois, uma boa tática de guerra na ofensiva antirreligiosa. Alvos não faltam: os padres, os relatos bíblicos, os mistérios da fé, o culto e até o próprio Deus", relata Minois, recordando que o "método mais comum" dessa ofensiva "é a desvalorização blasfematória, que iguala o sagrado ao trivial" (MINOIS, 2003, p. 504-505).

É o que ocorre com "O poeta moribundo", em que o eu-lírico desafia a instituição religiosa hegemônica do cristianismo, por meio do escárnio de um de seus mais importantes sacramentos, o da extrema unção, que realiza a passagem individual do mundo profano e terreno para o sagrado e divino.

Em seu estudo sobre a Morte no Ocidente, o historiador Philippe Ariès (2003, p. 32-33) observa que o cerimonial da Morte nas descrições literárias medievais cumpria uma sequência 
de três atos: 1) um lamento da vida, evocando os seres e as coisas amadas; 2) o apelo, a reunião e o perdão dos companheiros; 3 ) o esquecimento do mundo e o encaminhamento da prece a Deus - ato dividido em duas partes: a) a culpa e a penitência; e b) a encomendação da alma (commendatio animae), momento final em que se introduz o único ato eclesiástico, o da absolvição sacramental.

Como anuncia o título do poema de Álvares de Azevedo, o eu-lírico é um poeta "moribundo", isto é, posicionado num ritual de espera da Morte. Se recuperarmos o poema naqueles momentos apontados anteriormente, a partir dos diferentes sentidos dessa espera, verificaremos como eles se ajustam à estrutura ritualística cristã medieval: o poema começa com um chamado aos amigos e um anúncio do legado do poeta que vai morrer; em seguida, o poeta recorre à memória da vida vivida para lamentar sua partida futura; parte então para uma reflexão sobre seus vícios e virtudes durante a estada entre os homens; e recebe, afinal, a proclamação do Juízo e da punição, depois da qual entrega a alma à vida no Além. Entretanto, as imagens que se sucedem no poema contradizem as expectativas do ritual de Morte: vimos que a companhia dos amigos é conclamada para que usem a tripa do cadáver do poeta em cantos de louvor à Vida; que a memória desta não evoca apenas momentos benfazejos; que o poeta se orgulha de sua vida desregrada e a punição parece-lhe melhor do que ser salvo, pelo que ele prefere entregar a alma ao inferno, do que ao "céu dos tolos".

O momento mais importante da cerimônia - já que o mais religioso - é o terceiro ato, quando a atenção se desvia do mundo profano para o espaço divino. Aqui a alma enxerga-se pelos olhos da norma religiosa, mede-se segundo um olhar supraterreno e se entrega ao julgamento e à sentença da religião. É justamente nesse momento que o sarcasmo do eulírico atinge seu paroxismo crítico, já que "o riso anticlerical e antirreligioso visa liberar o espírito não somente na forma, mas também no conteúdo. Por isso, deve estar carregado de agressividade, é um riso guerreiro" (MINOIS, 2003, p. 504). Os ataques às expectativas emocionais e religiosas assumem então sua feição de blasfêmia a partir da quinta estrofe, em que o cadáver aparece corporificado, uma vez que os dois últimos versos exibem uma ambiguidade sutil e reveladora. Diz o poeta: "Ora, façam ideia que ternuras / Terá essa lagarta posta ao fresco!"” (versos 23 e 24). Apontei acima a metonímia presente neste verso, pela associação da lagarta com o verme que agencia a decomposição do cadáver. Resta agora notar que a metonímia tanto pode ser uma 
referência à Morte como também ao cadáver, isto é, ao poeta morto. No primeiro caso, as "ternuras" apontam ironicamente para os efeitos da Morte sobre o indivíduo e a consciência; no segundo caso, a "lagarta posta ao fresco" se referiria então ao próprio poeta cadavérico e sua "existência" post-mortem, ou ainda, ao seu sentimento pessoal da Morte diante da sua proximidade. A partir daí, como já vimos, ele desfia suas percepções de indivíduo perante a Morte e a visão religiosa do Além.

O eu-lírico começa, ao contrário do moribundo "clássico", não invocando o perdão, mas indicando para si as "caldeiras do terceiro inferno", se estiver errado no que pensa e espera da Morte. Se considerarmos que, na arquitetura infernal da Divina comédia, de Dante, o terceiro inferno é guardado por Cérbero e abriga os glutões, símbolo emblemático do homem desregrado nos prazeres, notamos como a expressão antecipa os "homens gozadores" do verso 33 e resume os pecados admitidos pelo eu-lírico no poema, que são os mais materiais, os derivados diretamente dos excessos do corpo físico: a gula, a luxúria e a preguiça. Tamanha atenção sobre os pecados dos prazeres físicos é índice de uma consciência aferrada ao gozo do mundo, aprisionada ao culto da Vida e não, contrariamente, às paragens apaziguadoras e inertes da Morte. Este não é um homem ansioso pela passagem a um mundo melhor, mas alguém que lamenta e zomba de um deus que não lhe permite o gozo eterno da vida mundana.

Por isso, o eu-lírico escolhe a outra margem, posicionando-se ao lado de mulheres belas, mas sabidamente "pecadoras". Cleópatra, Helena, Eleonora foram eternizadas por suas culpas: Cleópatra seduz, destrói e se mata; Helena provoca a guerra mais miticamente famosa do Ocidente; Eleonora - heroína da balada de Gottfried August Bürger, que arrebanhou admiradores brasileiros na tradução de Herculano blasfema contra Deus diante da morte do amado. Ironicamente, o último nome rima com as "Senhoras" do verso 32, mas antes internamente com o "namora" do verso 31, traçando uma triangulação sonora entre o eu-lírico - que namora - e as duas situações entre as quais ele se põe para fazer sua escolha, já denunciada pelo significado sensualista do verbo. Os fonemas da palavra "Eleonora" guardam ainda aliterações com os nomes das mulheres predecessoras, constituindo quase um anagrama da união das outras duas; e, de fato, das três personagens, esta é a que mais se ajusta ao poema e ecoa os temas tratados, afinal sua história é a de uma mulher obrigada, por castigo pelas 
blasfêmias, a desposar um noivo-cadáver, como o que ocorre com nosso poeta moribundo.

O último golpe contra a religião cristã e sua ritualística é aquele "DeusPreguiça", que diviniza o vício, ao mesmo tempo em que, individualizando a divindade, desvia o sentimento religioso do eu-lírico para o paganismo.

Todo esse ataque à cerimônia fúnebre, contudo, só foi possível mediante o uso do humor e da ironia, sem os quais o medo da Morte retornaria para assombrar o sujeito e seus terrores culposos. Na mascarada, "é preciso fazer barulho e rir muito alto para expulsar o medo. [...] Ri-se para ter segurança: as relações, que aparentam alívio geral, testemunham inquietações" (MINOIS, 2003, p. 473-474; grifo meu). A Morte não está, portanto, sendo exaltada, como já se disse que era opção poética da geração ultrarromântica. $O$ que se vê, aqui, é uma atitude de revolta "mascarada" contra a Morte e contra a religião, que a encobre, procurando iludir suas formas e impô-la ao indivíduo como destino coletivo sagrado e desejável. Em Álvares de Azevedo, a Morte desliga-se de seu vínculo com a instituição religiosa, o que lhe conferia uma aura benfazeja de passagem para um mundo melhor, recusado, aqui, na opção do eu-lírico pelo inferno.

Filiando-se às festividades populares medievais e às mascaradas revolucionárias, este poema de Álvares de Azevedo é um dos que o alinham entre os herdeiros de Byron, no Romantismo, e dos poetas marginais, na Idade Média.

Por um lado, "O poeta moribundo" revela inúmeros pontos de contato, por exemplo, com o "Lines Inscribed upon a Cup Formed from a Skull" ("Versos Inscritos numa Taça Feita de um Crânio"): o apelo ao canto amigo depois da Morte; a tripa servindo à música em Azevedo e o crânio servindo à poesia, de Byron; a ironia amarga do sujeito aniquilado pela Morte. Também o poeta do Childe Harold é recordado "acima de tudo pelas suas sátiras da maturidade, obras nas quais, no meio de um clima de serenidade estranho à vida, expõe a sua visão do mundo de uma forma irônica, que deve mais ao século XVIII inglês que ao modelo romântico" e, especialmente em Don Juan, utiliza "a personagem como reflexo, também irreverente e amatório, de um modo amoral e anticonvencional de considerar a vida", obra "onde se fundem surpreendentemente patetismo, sentimentalismo, humor e ironia numa conjugação magistral" (IÁÑ̃E, [19_], p. 25-26). 
Por outro lado, a herança azevediana neste poema, aliada, coincidentemente ou não, a uma vida formada nos ideais estudantis e marginais da Sociedade Epicureia, cria também linhas de confluência entre a sua poesia e a dos goliardos (ou "clérigos vagantes") medievais, também ocupados em destituir, pela poesia popular e humorística, a "nobreza" dos valores hegemônicos de sua sociedade (SPINA, 1994, p. 11). A transferência da liturgia para a literatura profana; a apologia da vida boêmia e devassa; a crítica ao sentimento religioso oficial e comum; a destituição das polaridades entre alto e baixo na poesia, tudo aproxima o bardo brasileiro dos poetas-estudantes medievais. Repare-se neste trecho das Carmina burana (compêndio da poesia goliarda):

\author{
Quero morrer, chegando o dia, \\ na taberna minha, \\ ao moribundo não deve faltar \\ caneca bem cheinha; \\ o coro dos anjos então trará \\ esta celeste canção: \\ "Deus tenha piedade \\ deste beberrão!"
}

(Carmina Burana, 1994, p. 93).

A expectativa da Morte também incita ao poeta o pedido aos amigos que ficam: não falte bebida no velório; o "minha” justaposto à taberna indica como foi - ou, antes, onde foi - passada a vida do poeta; segue, como no poema de Álvares de Azevedo, o Juízo e o anúncio da sentença; nesse caso, o eu-lírico aparentemente pede salvação, mas o pedido é destituído do mérito pela falta de seriedade do "beberrão" no fim da estrofe (no original, potatori).

Com estas observações, espero colaborar com aqueles que recusam ver no poeta da Lira dos vinte anos uma consciência faltosa dos sentimentos dos outros homens e avessa, assim, à poesia denunciadora das mazelas "sociais". Pelo contrário, a obra azevediana ataca o sistema cultural do Ocidente em seus fundamentos. A poesia "social" de Álvares de Azevedo não é ingênua nem local, por isso a dificuldade de tantos leitores em avistá-la nos seus poemas. Sua crítica arrebanha os povos, é um grito contra a condição do homem e das massas, e não somente um manifesto de indignação 
contra uma injustiça particular; um libelo contra todo o espírito do Ocidente, e não apenas contra uma corrupçãozinha regional.

Acrescentemos que, embora surgido de um sentimento egocêntrico e de sua recusa da aniquilação niveladora da Morte, graças ao humor, o poema de Álvares de Azevedo evita uma poética particularista e subjetiva. Tomar o Eu para derruí-lo não é menos subjetivista que tomar o Outro para expressar-se? No humor, a emoção patética e pessoal é sempre evitada.

Finalmente, tomo, para conclusão, um comentário de Antonio Soares Amora (1969, p. 158), para quem seria insuficiente explicar o êxito da "poesia de morte" azevediana apenas pela moda ou pela suscetibilidade juvenil ao tema, bem como pela ânsia de salvação resultante do sensualismo e hedonismo da geração. De fato, pela leitura de "O poeta moribundo" notamos que, se a Morte não era novidade na poesia da época, distinto era, porém, o sentimento que o poeta paulista lhe imprimia, seguindo os passos sarcásticos dos byronianos. Além disso, não se pode falar em desejo de Morte para poetas com tamanho senso de individualidade, muito menos em "desejo natural" de morte em casos como o desses jovens. O que dizer, então, de um desejo de salvação, se todo o ritual de passagem está suspenso pelo riso e pela paródia?

Esta é talvez a grande novidade da Morte na poesia de Álvares de Azevedo: sem a religião institucional, a Morte é sentida em sua nudez. A religião parece impotente diante do sofrimento individual da Morte, inútil na mitigação da dor de morrer, tão pessoal e intransferível. Em sua morte, o poeta romântico está absolutamente só. O que não quer dizer isolado, pois, se existe algo que, acima de qualquer outra coisa, favorece o sentimento de fraternidade, é a Morte, mãe terrível que assiste igualmente os filhos, um a um.

\section{REFERÊNCIAS}

AMORA, A. S. A literatura brasileira. 3.ed. São Paulo: Cultrix, 1969 (v. II: O Romantismo).

ARIÈS, Ph. História da morte no Ocidente: Da Idade Média aos nossos dias. Tradução Priscila Viana de Siqueira. Rio de Janeiro: Ediouro, 2003. AZEVEDO, Á. de. Poesias completas. Rio de Janeiro: Ediouro, [19_]. 
BOSI, A. História concisa da literatura brasileira. 3.ed. São Paulo: Cultrix, 1993. CANDIDO, A. Formação da literatura brasileira: Momentos decisivos. Belo Horizonte/Rio de Janeiro: Itatiaia, 1997 (v. 2).

CUNHA, A. G. da. Dicionário etimológico Nova Fronteira da língua portuguesa. 2.ed. Rio de Janeiro: Nova Fronteira, 1997.

Carmina Burana: Canções de Beuern. Tradução Maurice van Woensel. São Paulo: Ars Poetica, 1994.

DUCROT, O.; TODOROV, T. Dicionário enciclopédico das ciências da linguagem. Tradução Alice Kyoko Miyashiro et al. 3.ed. São Paulo: Perspectiva, 1998. GOMES, E. O individualismo romântico: Álvares de Azevedo. In: COUTINHO, A. (Org.). A literatura no Brasil. 4.ed. São Paulo: Global, 1997 (v. 3: Era romântica). GREIMAS. A. J.; COURTÉS, J. Dicionário de semiótica. Tradução Alceu Dias Lima et al. São Paulo: Cultrix, [1983].

IÁÑEZ, E. História da literatura: O século XIX - Literatura romântica. Tradução Fernanda Soares. Lisboa: Planeta, [19_] (v. 6).

MINOIS, G. História do riso e do escárnio. Tradução Maria Elena O. Ortiz Assumpção. São Paulo: UNESP, 2003.

MORIN, E. O homem e a morte. Tradução João Guerreiro Boto e Adelino dos Santos Rodrigues. 2.ed. Lisboa: Europa-América, [1988].

NIETZSCHE, F. A filosofia na época trágica dos gregos - Anaximandro de Mileto. Tradução Rubens Rodrigues Torres Filho. In: SOUZA, J. C. de. (Org.). Os présocráticos. 4.ed. São Paulo: Nova Cultural, 1989.

ROSENFELD, A.; GUINSBURG, J. Romantismo e classicismo. In: GUINSBURG, J. (Org.). O Romantismo. São Paulo: Perspectiva, 1978. p.261-274.

SPINA, S. Apresentação. In: Carmina Burana: Canções de Beuern. Tradução Maurice van Woensel. São Paulo: Ars Poetica, 1994. p.9-12.

Artigo recebido em 10/04/2010. Aceito para publicação em 27/07/2010. 